\title{
SCIENTIFIC BREEDING OF ANIMALS AND PLANTS
}

\section{BY M. HAMILTON TALBOT}

The problem of finding food for the new millions which are being added to our population-at the rate of 4,000 a day-with the area of the country not increasing at all, looks like a serious one. The solution, however, is found in the new science of breeding, which is adding other grains to the ears of wheat and corn, producing two blades of grass where one

do not equal this. Luther Burbank, the dean of the American school of plant breeders, recently said: "The right man under favorable conditions can make one dollar yield a million dollars in plant breeding." The twentie ${ }^{\text {th }}$ century scientist in looking for food for the new millions found Nature too slow, so he took the grains and the fruits and forced the most iages; and in

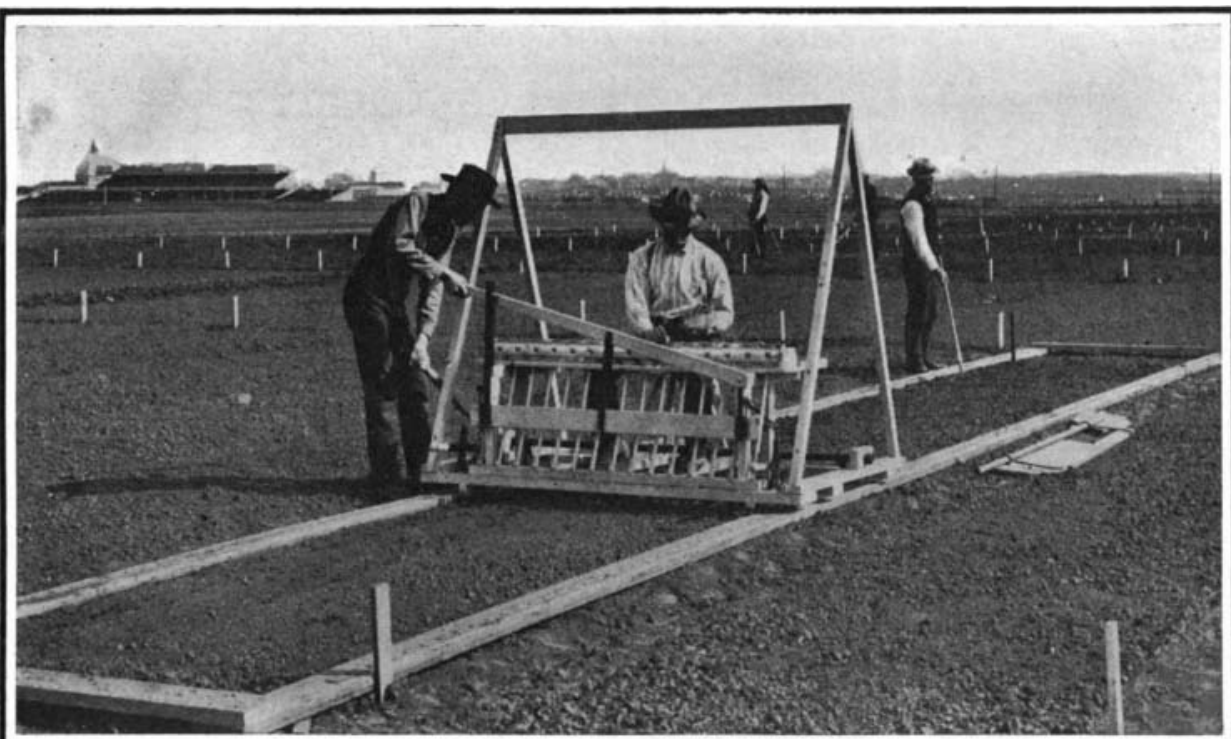

Planting centgeners (100 hill plots) in crop nursery.

place of natural selection, the law of wild life, he $h$ a s established artificial s e lec. tion, which is faster and a thou sand times better adapted to human needs. He has created new wheats able to withstand gre a t cold, new corns rich in fats or in proteid s, new potatoes with a larger su gar content than ever veloped hardy oranges, plu m $\mathrm{s}$, apples, and other fruits; long-staple c o t t o n s, high-

grew before, and giving us superior breeds of animals. The work accomplished by scientific plant and animal breeding in the pa Treeding in the past decade has already increased the cent, and ten to twenty per cent of increase on four billion dollars worth of our farm crops and three billion dollars worth of our animals means approximately a billion dollars annually in additional profits to our farmers, and all at a trifling cost. The investment of every dollar in scientific breeding vields hundred dollars, or ten thousand per cent. Gold yielding cereal grains, and various other plants never before seen on our planet.

Heredity is the science which is originating these new plants and new animals, and it is rapidly coming into man's hand to be used to increase production. Scientific breeders believe that every species can be improved by breeding, that every species has in it a blood strain with rare value for producing along desired lines, rare centgener power. The - ord centgener, which has been coined for use in expressing the breeding power of the individual plant or animal, is a com. bination of centum and gevera, which means a hundred (more or less) of one birth having a common parentage. Breeders search for this phenomenal strain, and when found-the one in many-all others are discarded, and this superior blood is multiplied,

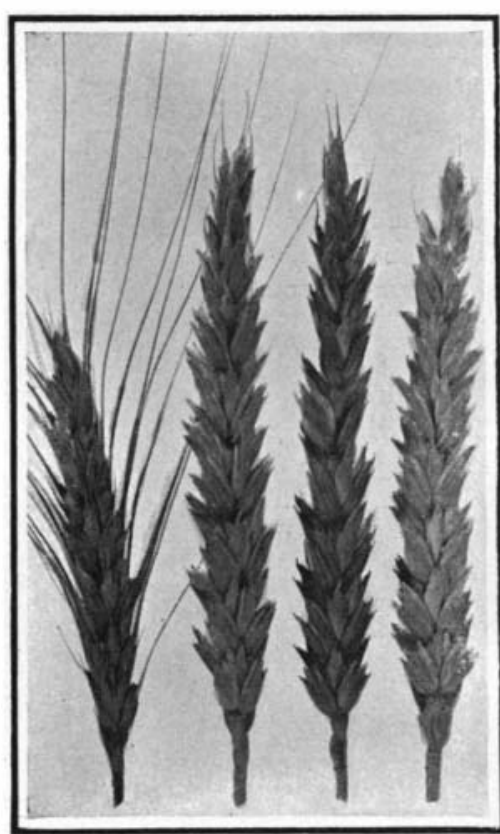

Hybrid wheats produced by scientific breeding. The two middle wheats are hybrids resulting from a cross fertilization of the two outside varieties.

and made to take the place of their half-civilized brothers. By this centgener method the breeder first secures many superior plants, and a hundred or more of each parent are planted; and by comparing the average of the progeny of the respective parent plants, the power of each parent to project its own individual values into its progeny is measured, and the seeds of those relatively few parent plants which beget the best strains are preserved and made into new purebred varieties By this means the parent plants are (Continued on page 4 .

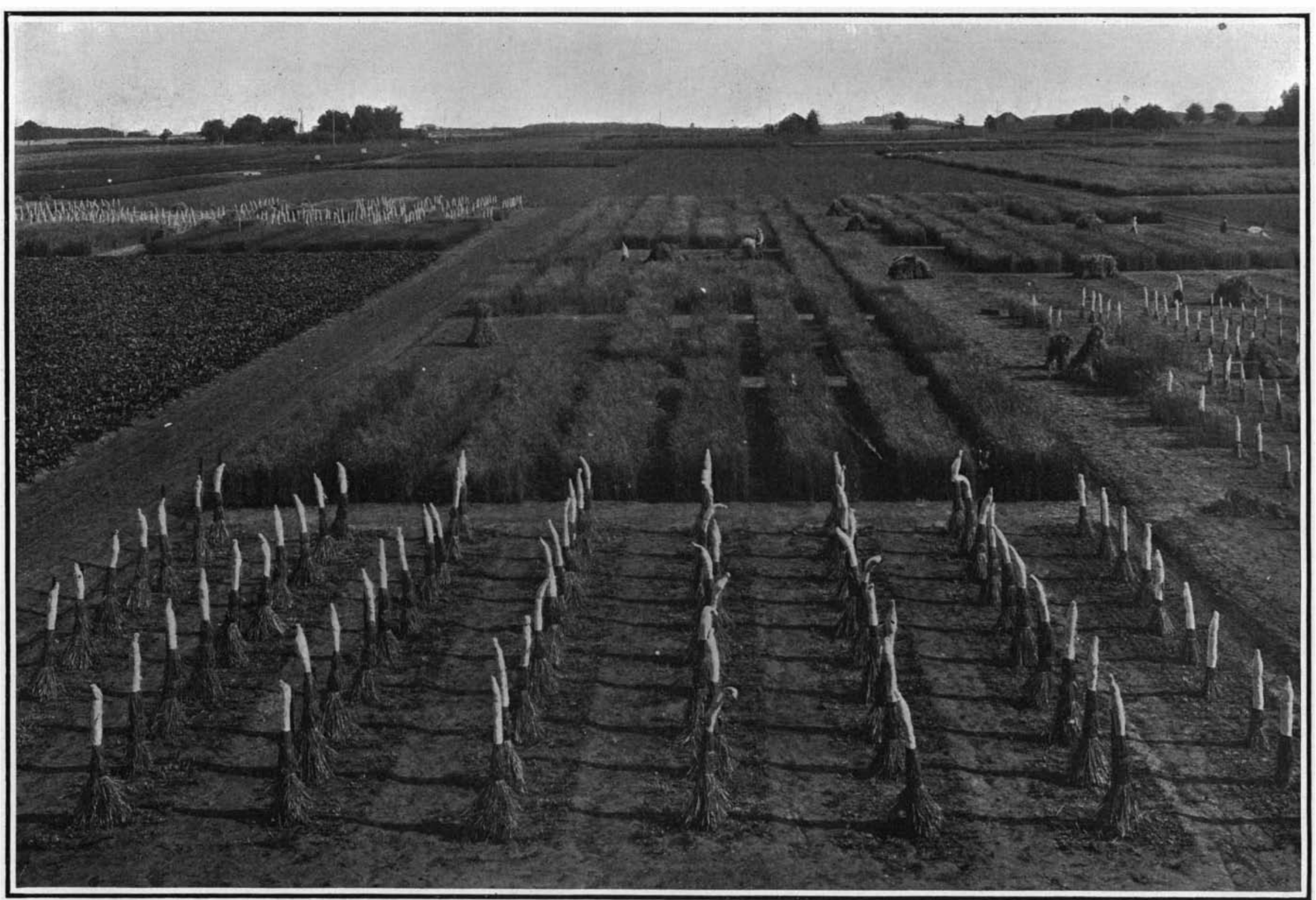

The crop nursery at the Minnesota experiment station.

Showing how new varietiea, such as flax, wheat, and clover, are originated, and old ones improved. Frect bundles of grain in foreground are each of new quality of whear carefully harvested and tied np with cloth to prevent loss of grain. 
Classified Advertisements Adverhisements welded together with two side sheets, form Cos terminating in the than four nor more than 10 lines accepted. Count

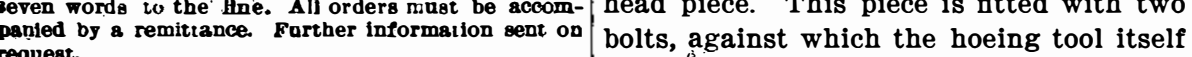
READ THIS COLDMN CARRFOLLY, - You will And is pressed by a spring flued between the

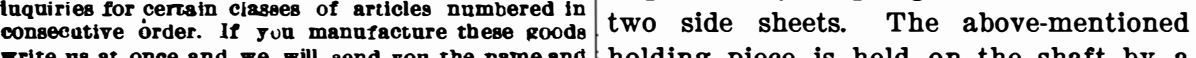
no charze for tbis service. In every cane it is spiral sping, wound around, allowing peessary to give the number of the inquiry
Wherg mann acturers do not respond prompty the

MUNN \& Co.. Ine.

BUSINESS OPPORTUNITIES.

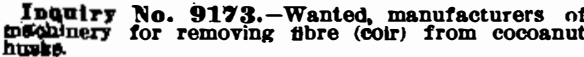

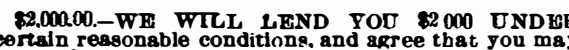

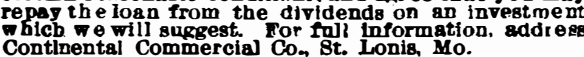

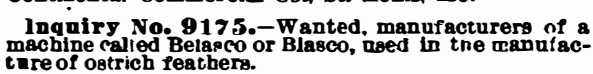

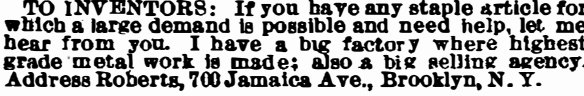
Inqniry. No. 918 - Wanted,
rubeer bluck tires for ore ton tructs.

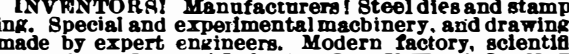

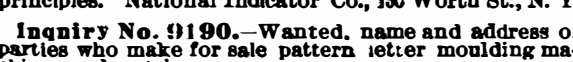

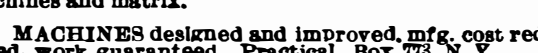
Inqpiry No. 9202. -Wanted, to buy the Rose
sountain yen

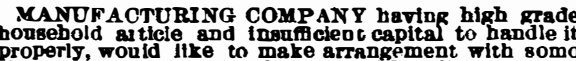

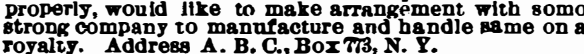

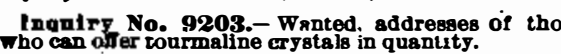

PATENTS FOR SALE.

nectraple holder. 9204.-Wanted, to bny non-Dinding

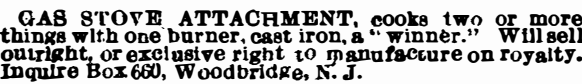

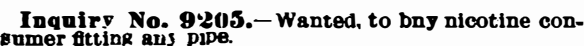

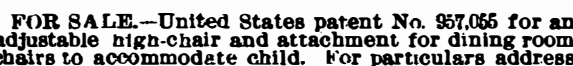

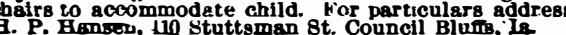
Inquiry No. 9201i- - W anted, manufacturers to seel
castrings such as hammerro in the rough.

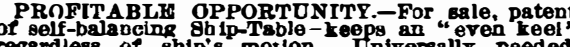

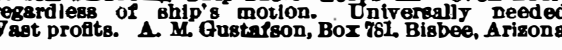

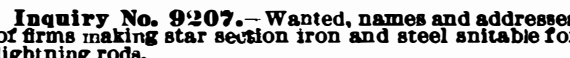

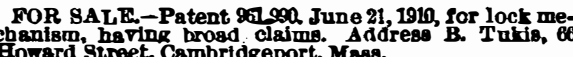
Ingpiry No. 9208.-Wanted, the address of the
mannfacturer of the "Little Giani" Pump.

\section{HELP WANTED.}

1nquiry Noo 9209.-Waated, names of ormers of
gold placer propertities

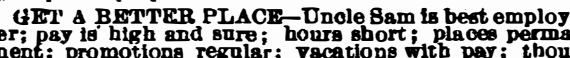

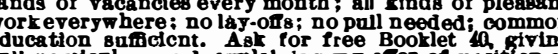

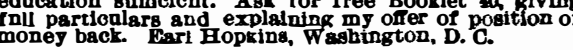

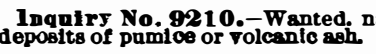

LISTS OF MANUFACTURERS. Inquirg No. 9211. - Wanted. addresses of parties
Tho can ghis ore containing. vanedium, molybdezinm CUMP1.ETE LisT's of manufacturers in all lines sup
plied at short notice at moderate rates. Small and

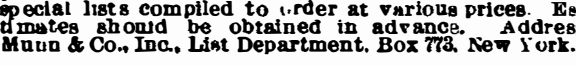
Inquiry No. 9212. - Wanted, names and addresse
of owners of thor spar properties.

SALE AND EXCHANGE. Inquiry No. 8213. - Wanted, addresses of partie
matrog

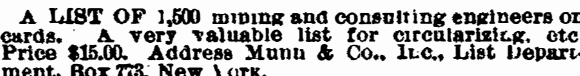
lnguiry, No. ger14.- Wanted, address of maker
of "Plako," a fastening for ladies'dresses. 1natiry No. 9215.- Wanted. machine for prod 1napiry No. 9216.- Wanted, to buy a se
chine baving a very loug arm for suecial morz. Tnquiry Noo 9217. - Wanted, the names and ad
dresses of manufecturers of macbinery for sbelling as
monds and peanuts. Inquiry No. 9218.- Wanted, the names and ad-
dresses of manufacturers of outtats for salting admonds Inquiry No. 92819. - Wanted. names and addresse
of manufacturers of bags, cartons. and oiled and waxe

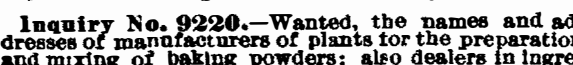

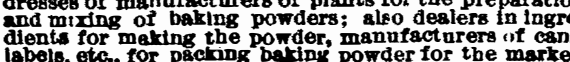
Inguirv No 9221 - Wanted, names and addresee
of owners of mica properties. Inquiry Yo 92aze. - Wanted, names and addresse
of owners of White sillica sand deposits. Inquirs No. 92233.-Wanted, to buy machiner
for making sugar of mill. Inquiry No. 9224.Inairy No 9225. - Wanted, a concern able

for a flexibility in any direction, while the spring, fixing the tool itself, permits giving away forward or backward and wiveling sideways, to avoid any oblater compels the tool to return to its riginal position.

The force actuating the hoes when he drum rotates is the centrifugal force combined with the gravity. The regulaion of the phase and the energy of sucblows is done by a latch mechanthe right moment and catching and holding. them again, after having perholding them again, after having per-
formed this work in the ground. The drum has a diameter of $3 \frac{1}{2}$ feet. In ront of the main driving tool may be placed a dovetailed forecutter, suited to cut the top grass clod and to tear it down into the spaces opened by the ain knives in order to have it buried nder the clods. Upon one hoe shaft rom 16 to 24 hoes can be placed side by side in the actual type of machine, allowing for working a strip 7 to 8 feet wide, sufficient for three rows of corn, cotton, or potato plants.

According to the work to be done, the hoes can be changed; light against heavy nes, pointed against flat ones, long ones gainst flat-working ones (peeling). The hanging is done by hand, without uncrewing any bolts and without requiring any special tools.

With one man to operate it and with gasoline consumption of two to three allons per hour, the following work is performed by the machine:

\begin{tabular}{|c|c|c|}
\hline & $\begin{array}{l}\text { Deptb, } \\
\text { Incles. }\end{array}$ & $\begin{array}{l}\text { Output, Acre } \\
\text { per Hour. }\end{array}$ \\
\hline 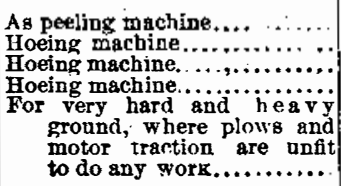 & $\begin{array}{l}3 \text { to } 4 \\
6 \text { to } 8 \\
8 \text { to } 10 \\
10 \text { to } 14 \\
6 \text { to } 8\end{array}$ & $\begin{array}{c}1 \text { to } 2 \\
\text { tisto } 1 \\
0.45 \text { to } 0.96 \\
0.40 \text { to } 0.80 \\
0.40 \text { to } 0.80\end{array}$ \\
\hline
\end{tabular}

Studying these flgures, it must be con sidered that the machine renders the soil ready for sowing, and it hauls any
roller or sowing machine attached to it, when performing its work.

\section{SCIENTIFIC BREEDING OF ANIMALS AND} PLANTS.

(Continued from page 440.)

compared in a far more vital way than y simply comparing their yields.

This centgener method of breeding was originated by the Hon. W. M. Hays, Assistant Secretary of Agriculture, who stands at the head of a group of men who are conquering a new earth. More than wenty years ago he began experimenting with our field crops, trying to increase their yield, and his unique methods have been developed into a system with a most wonderful organization of detail in selecting seeds, planting large broods of single mother plants, recording the performance of individual plants, and in tabulating and displaying the pedigree values of the thousands of newly created pure-bred vaieties, which is now recognized as the most important method followed by scien tific breeders.

Interest in this new science has been awakened all over the country, as is evidenced by the fact that establishments whose task is to create new heredity alues are being built in many of our States. Minnesota, Nebraska, Iowa, Colo rado, Wisconsin, North Dakota, South Dakota, Kansas, Ohio, and a number of other States are actively engaged in forwarding this work. The United State Department of Agriculture is developing specialists, each trained in breeding certain species, who are co-operating with
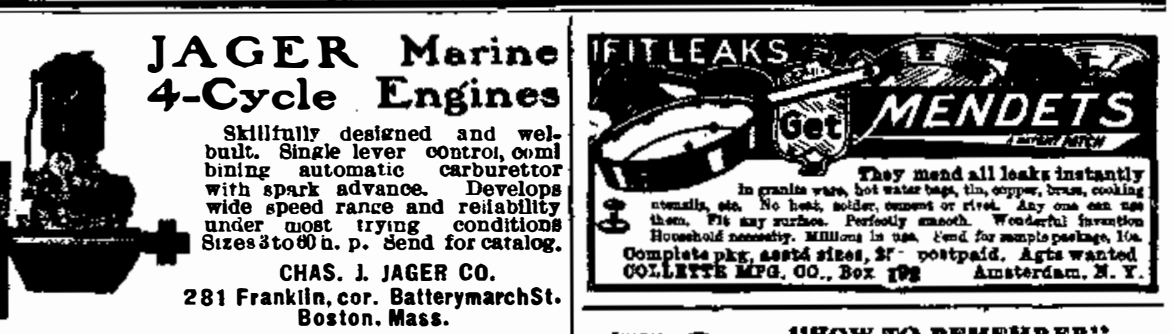

Wizard Repeating LIQUID PISTOL

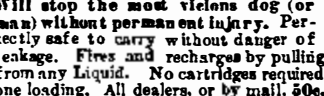

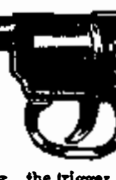

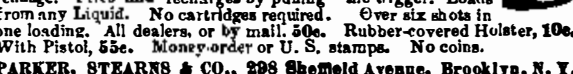

Manufacturer of Patented Articles, Models, Tools, Dies,

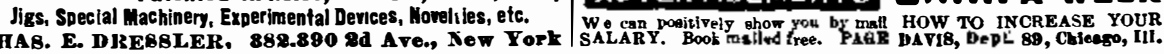

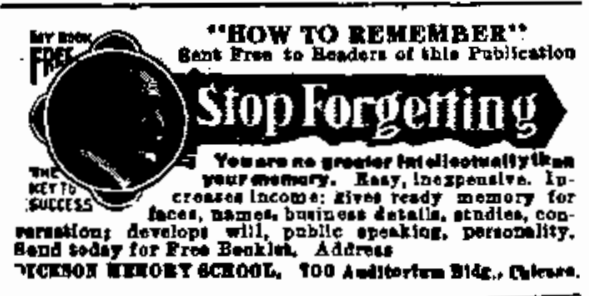
"HOW TO REMEMBER":

LEARN TO WRITE FARN\$25to\$100

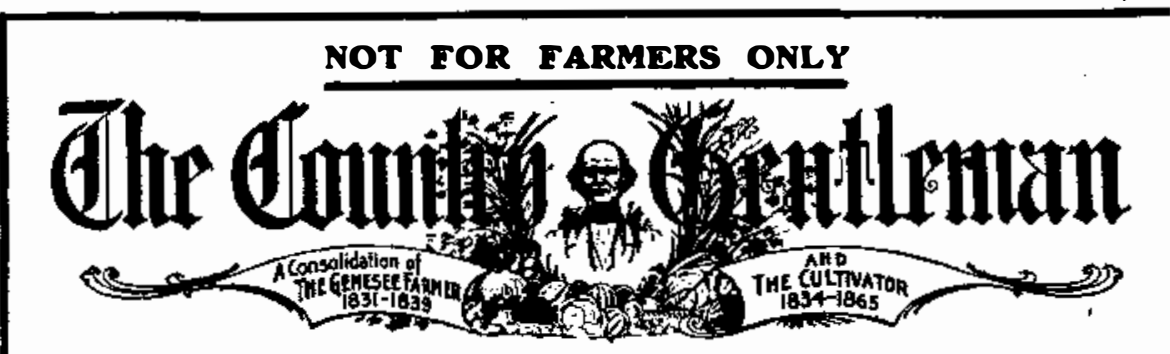

The Leading Journal of Agriculture

The ONLY Agricultural NEWSpaper

but also

The one weekly devoted to country life which no suburban resident and no city owner of a country place can afford to be without.

Subscription, \$1.50. Three Subscriptions, or Three Years, \$3.

SPECIMEN COPIES FREE, It will pay anybody interested in any way in counLUTHER TUCKER \& SON, ALbany, N. $r$.

\section{W O O D DIST ILLATION} ALCOHOL

AND OTHER PRODUCTS OF THE PROCESS

Profits from refuse wood and sawdust are in reach of any one who will locate near a sawmill. The Scientific American Supplement files contain a series of valuable articles on this topic which are contained in the following numbers:

No. 1610 A General Review of the Subject of utilizing wood wastes, and the uses to which the wastes may be put.

No. 1684 The "steam" and "destructive" distillation processes, and names the numerous products obtainable from the complete operation.

No. 1661 Distillation of soft wood, and gives the proportions and quantities of each product obtainable, and the various processes used.

Nos. 1723 and 1724 The general subject of the utilization of wood wastes, giving all the products by a clear and valuable diagram showing their relations to each other, and many illustrations of apparatus.

No. 1592 The manufacture of wood alcohol by a German process which first converts sawdust and scraps to glucose and then to alcohol, leaving the residue of the wood with $75 \%$ of its heating value, and in condition to briquette without a binder.

No. 1789 Prof. Ruttau's article on the manufacture of wood alcohol, a very comprehensive discussion.

No. 1643 Dry distillation of Beech and other hardwoods comparing European and American methods, and giving the quantities of products obtained.

No. 1335 Charcoal manufacture in Germany, with complete recovery of

No. 1472 "Distillation of Pine Products" refers especially to turpentine manufacture, but covers the by-products as well, and gives information of the profitable nature of the business.

No. 1151 Refers to acetic acid, wood spirit and acetone from distillation of wood, and gives a good description of the necessary apparatus, and particu-

No. 1736 Production of Alcohol from Cellulose, how wood and wood products may be used.

Each number of the Supplement costs 10 cents. A set of papers

containing all the articles above mentioned will be mailed for $\$ 2.40$ Odder from your Newrdealer or from

MUNN \& CO., Inc., Publishers, 361 Broadway, New York City FOR THE MANUFACTURE OF by-products, their description and uses. larly of the points to be observed in operating the plant. 


\section{THREE NEW BOOKS}

Drop Forging, Die Sinking and Machine Forming of Steel

\section{BY JOSEPH V. WOODW ORTH}
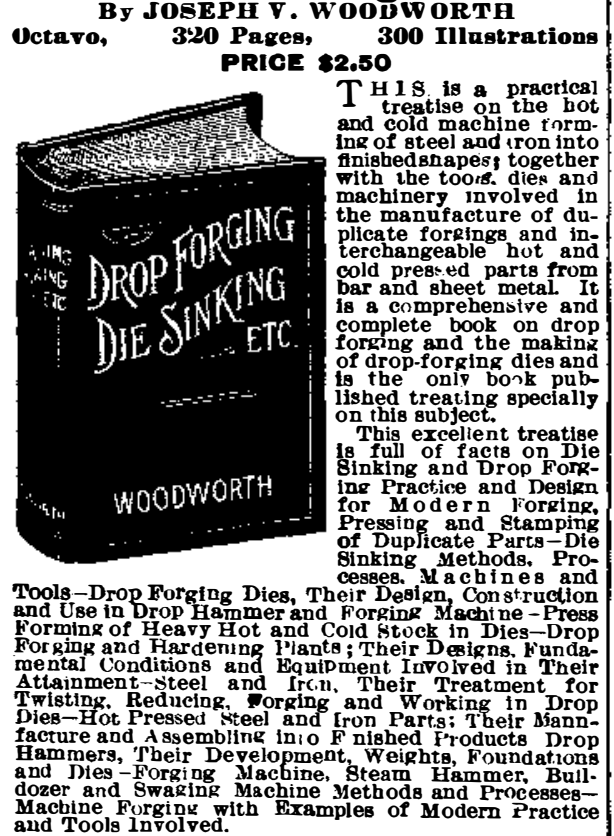

Standard Practical Plumbing By R. M. STA RBUCK
Author of "Modern Plumbing llustrated," etc., etc.

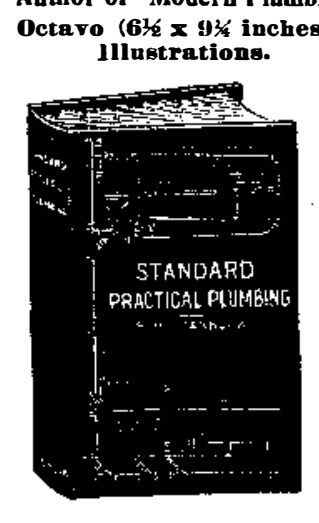
406 Pages,
Price \$3.00.
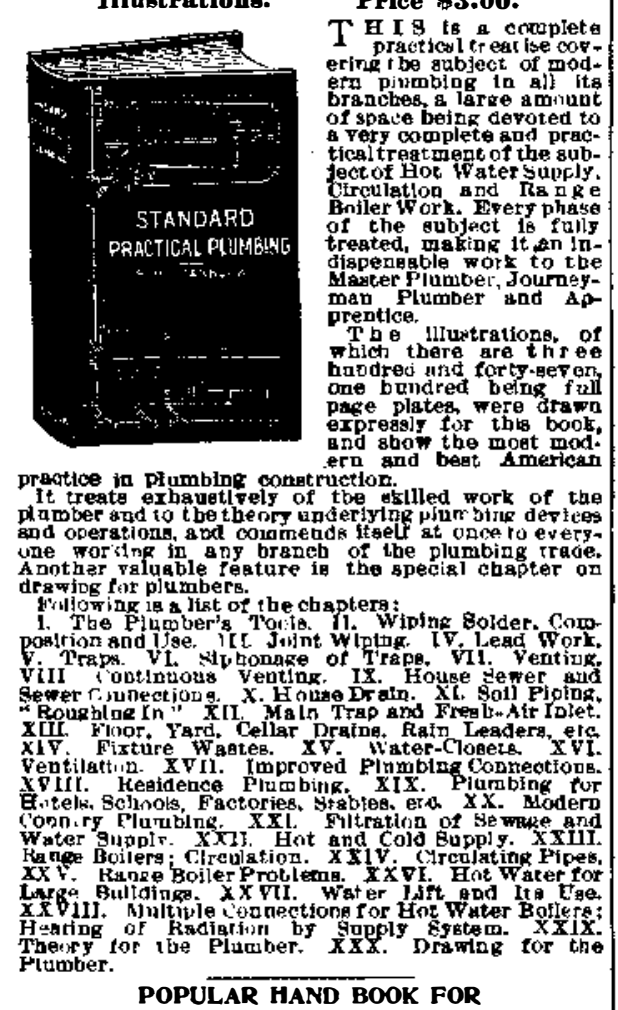

Cement and Concrete Users By MYRUS H. LEW 1s, C. R. ALBFRT H. CHANDLER, G. R.
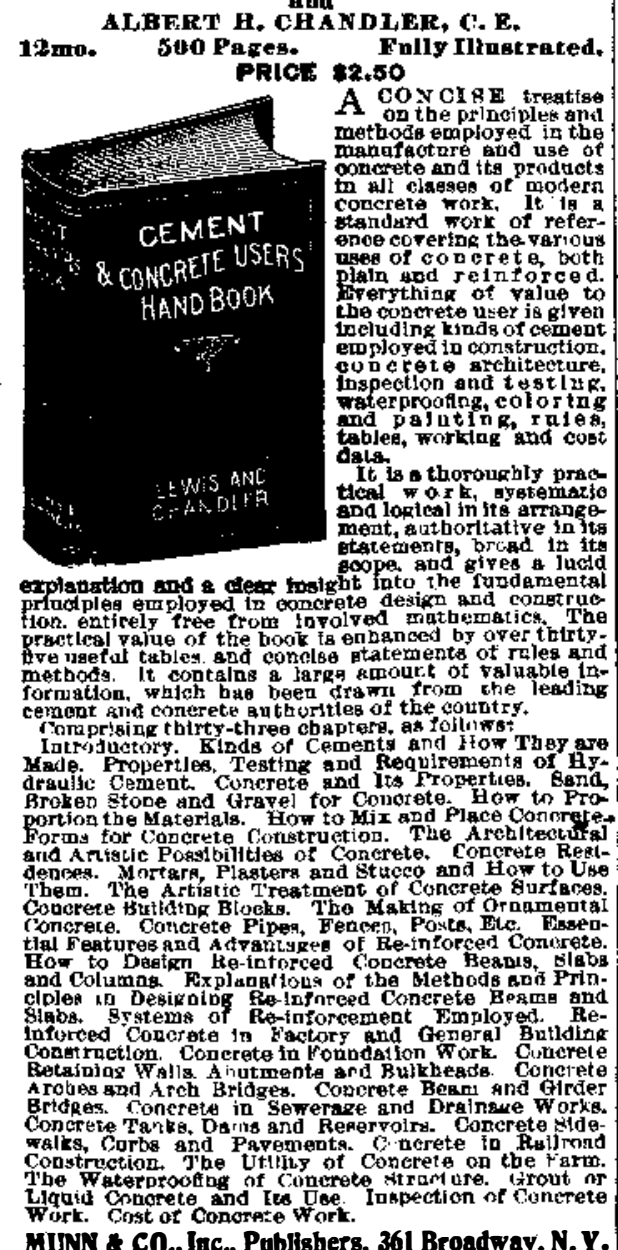

all public institutions and also with pri- $\$$ 40.00 MOTORCYCLE This This great national movement to pro-
mote scientific breeding also led to the formation of the American Breeders' Association, an organization which has more than fifty committees at work on the different phases of plant and animal breeding. It has committees on breedin draft horses, driving horses, saddlers, dairy cows, beef cattle, and dual-purpose and milk; committees which deal with the improvement of sheep, swine, poultry, pet stock, fur-bearing animals, and game birds, also committees which formulate the best plans for the breeders of wheat, of corn, and of alfalfa, and in
fact on all questions relating to the breeding subject. Under the leadership of this association, in conjunction with culture and the Minnesota Experiment Station, a co-operative association breeders has been formed, whose object
is to create and distribute new breeds and sub-breeds of animals. Certain territorie called "circuits," comprising twenty or more breeders, are each under the car of a superintendent, whose salary charge
is evenly divided between the association the Experiment Station, and the Federal government. It is his duty to trave around among the breeders and aid them in breeding their herds, and also to fin dation stock to be secured in this country or abroad. Each breeder in return
for this public service agrees to work for this public service agrees to wor sisting of a representative of the associa tion, the station, and the department. Each co-operator signs a bond to ow and breed at least five females and on male of type approved by the board, to
feed and manage them in accordance with the will of this body, and to sell stock of the first class only to other
members of the association. Animals not chosen to breed in the circuit may be registered in the national register for of pure-bred cattle, but defective animals must either be destroyed or sold only to breeders of common cattle. This plan avoids public ownership, and allows each dreeder, within certain

These men who are harnessing up and using the forces of heredity have already added vast millions to the wealth of the country, as already stated. The potato
originated by Luther Burbank in his boyhood has yielded probably the largest aggregate of additional wealth of any new things created. Other men like him have braved derision, discomfort, and
privation to demonstrate their belief in privation to demonstrate their belief in
the subtle forces of heredity. Not less than a million dollars may be found on the Northwest by the creation of a single
the variety of apple, called the "Wealthy," whose peculiar heredity enables it to It was originated by a man named Peter It was originated by a man named Peter Gideon. A variety of wheat known as
"Minnesota No. 169," which yields nearly twenty bushels an acre more than ordinary wheat, was originated at the Minnesota Experiment Station, and has now spread to more than a million acres, increasing our wheat wealth millions of
dollars. The flax "No. 25" of this same station yields twenty-five per cent more seed than ordinary flax, and has crowded parents from hundreds of thousands of acres of land. Corn "No. 13" is now hardiness, carried the corn belt fifty miles farther north than it was before this variety was originated.

The breeding of field crops has greatly dearged such industries as flour milling, oil, and also the cattle business, for more corn makes more cattle, and all this in creased production and work increases the number of people in the State and In animal breeding too there 1 a

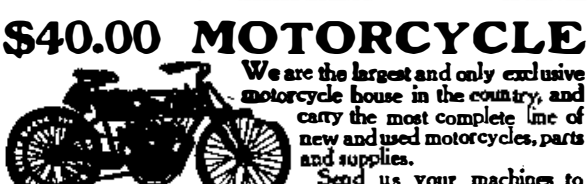

oct repeirs for ore be overhaulod. We carry in HARRY R. GFER CO., 851 MeLeran Are., ST. LOUIS. MO. WELL MACHINES

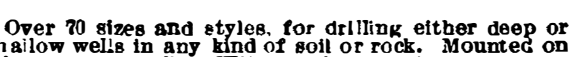
WILLIAMS BROS., Ithaca, N. Y.
W.

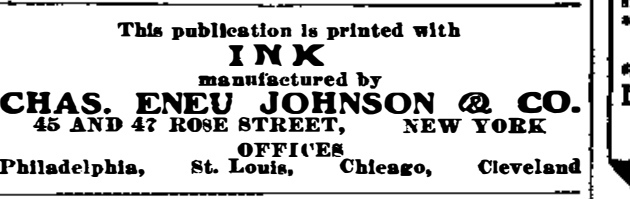

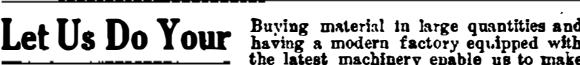

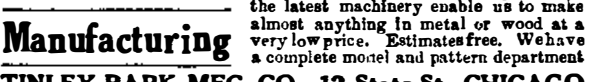
TINLEY PARK MFG. CO., 12 State St., CHICAGO IGE MACHINES MODELS E EXPERIMENTAL WORK. E. V. BAILLARD CO.. 24 Frankiort Street. New York. SOUTHERN STAMPING \& MFG. CO. RUBBSR Expert Manufacturers PARKER, STEARNS \& C0.. 288-290 Shefifield Av.,B'klyn,N.Y. Patented Art cles and Metal Specialties

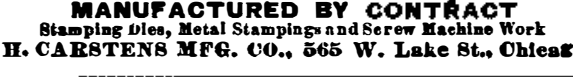

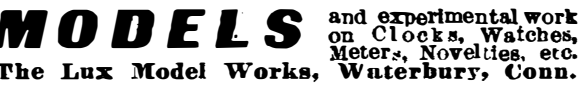
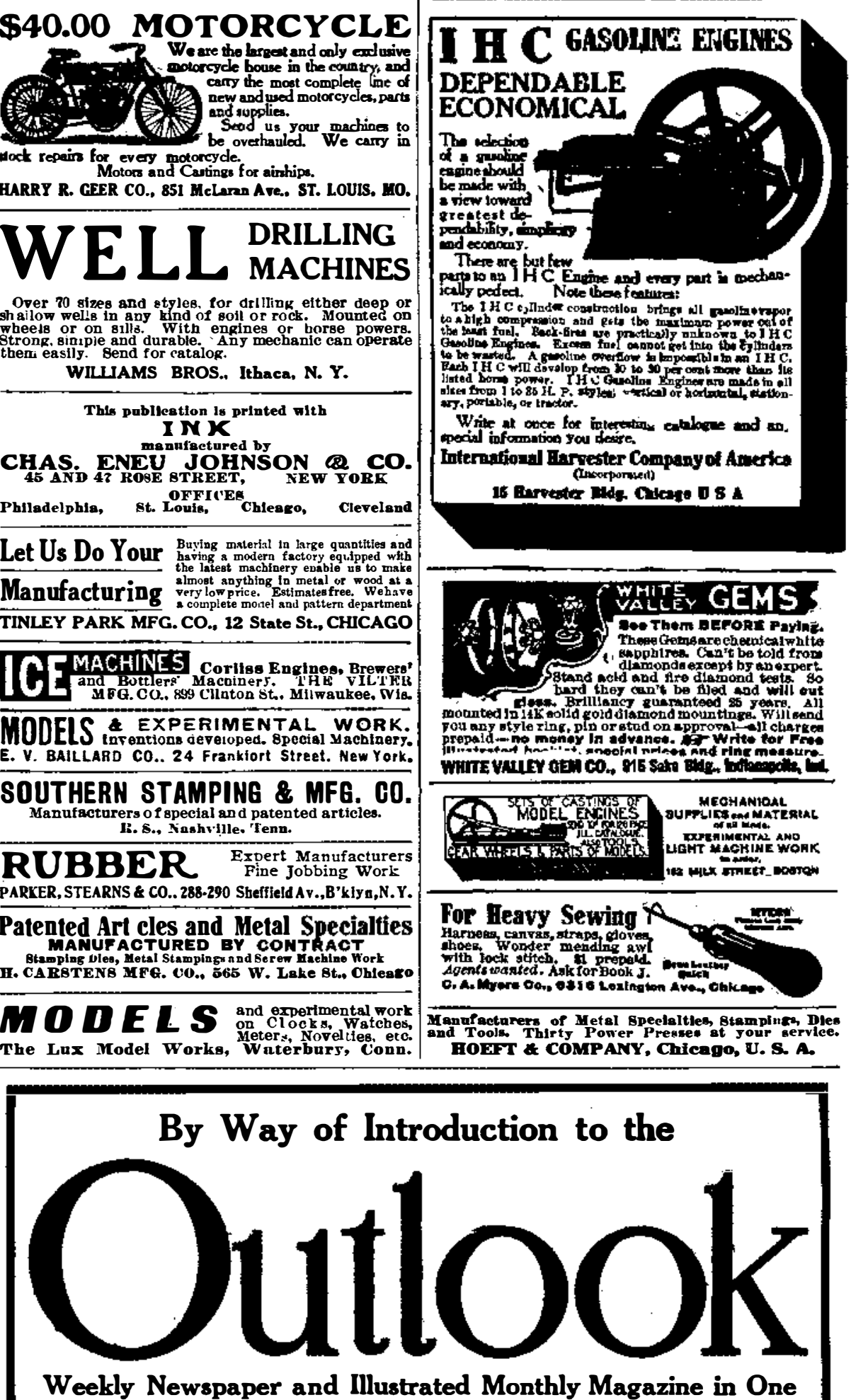

Weekly Newspaper and Illustrated Monthly Magazine in One LYMAN ABBOTT, Editor HAMII TON W. MABIE Anocinto Editor

TO other periodical has ever held exactly the position in the life of the Nation which The Outlook now occupies, and no other journal gives in the same efficient way the service which The Outlook renders to busy men and women who wish to keep accurately informed concerning the world's doings. As a Weekly Newspaper, The Outlook presents in paragraphs and editorial articles a concise record and interpretation of current history and current problems. Its contributed articles discuss those problems and that history in terms of human experience. As a Monthly Magazine, The Outlook presents in the fourth issue of each month a large and varied group of illustrated articles, each tested by standards of literary workmanship and each having a vital editorial reason for its selection. Those who read The Outlook regularly soon become its enthusiastic friends. Ask them what it is that makes The Outlook different from anything else, and why it is that The Outlook is so often quoted in politics, in business, andin the home.

\section{Theodore Roosevelt}

is actively associated with The Outlook as a member of its editorial staff, and those who wish to know what he really has to say on matters that concern the Nation's welfare will find his views fully expressed in The Outlook over his own signature. His writings on current topics do not appear in any other newspaper or magazine. Under the title "American Workers in Town and Country" Mr. Roosevelt will contribute three or four articles early in 1911 dealing with the social and industrial problems of the miner and farmer. The articles are based on his visits to the Pennsylvania coal mines and to the abandoned farms of New York.

"The New Nationalism" is the title of an attractive volume containing the important addresses of Theodore Roosevelt's recent Western Tour, carefully
revised by the author, with a descriptive introduction by Ernest Hamlin Abbott, who accompanied the party. It includes all the speeches that have aroused such insistent discussion

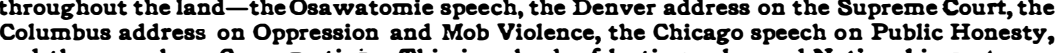
and the speech on Conservation. This is a book of lasting value and National importance.
The price of The Outlook is Three Dollars a Year. In order to introduce it to new readers we offer to present to any one not now a subscriber who sends Three sending The Outlook until the first of January, 1972. Send your order promptly, addressing THE OUTLOOK 287 FOURTH AVENUE NEW YORK 


\section{This Large FREE}

\section{Catalog}

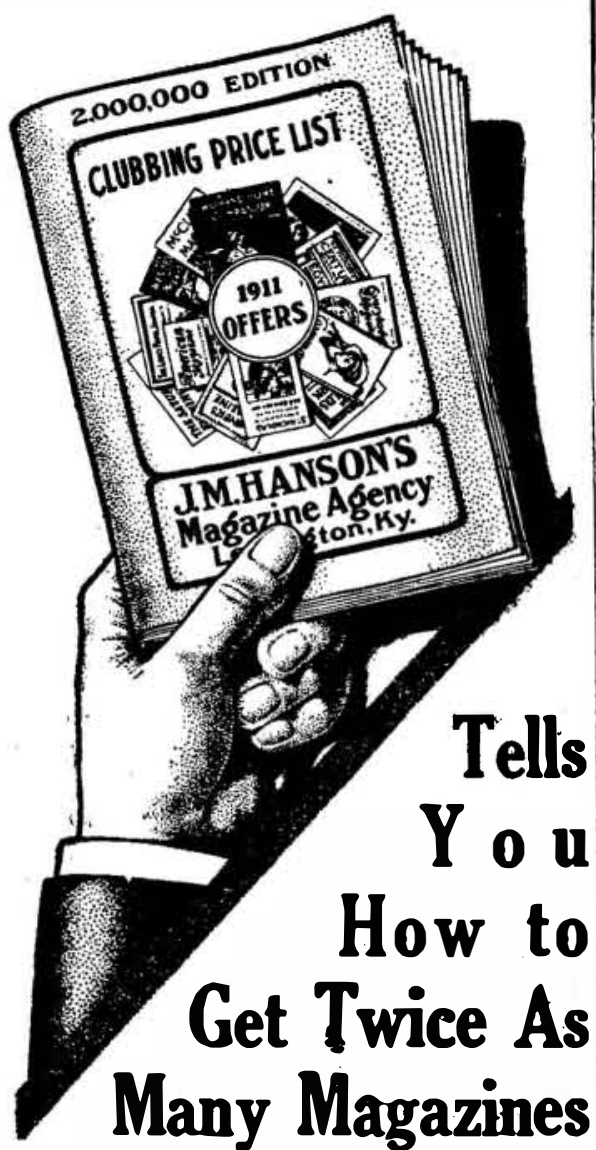

For the Same Money

A list of 3000 magazines, newspapers and clubbing offers-Unique in the subscription field because it offers almost every possible combination desired.

It is crowded with profitable-to-you-suggestions. You cannot afford to be without it.

J. M. Hanson's is the largest magazine subscription agency in the world-known everywhere.

Absolutely reliable and the most prompt in the magazine field.

\section{Save}

MagazineMoney

If your magazine money is limitedyou want to take more magazines, news papers, periodicals of any or every class you can do so without increasing your present expenditure.

Our long time contracts direct with publishers insure you this. Write to-day for our 1911 catalog-if you want to save on magazine money or increase your list with no greater expenditure.

Send for this FREE Catalog

A postal with your name and ad dress will do.

\section{J. M. HANSON'S MAGAZINE AGENCY}

240 HANSON BLOCK

LEXINGTON, amazing achievem $\in$ nts, Longer years, however, are required in this field for accomplishing results. Special breeds of bacon hogs, with long sides of uniform thickness with alternating layers of fat and lean, have been created through the efforts of the Minister of Agriculture of Ontario, Canada, in his efforts to gain in England a market for Canadian pork. The growers of cattle and users of meat have had a great wealth brought to their barns through the far-seeing patience of Cruikshank, the originator of the famous Shorthorn cattle, noted for their superior meat-producing qualities. In Colorado there is now being bred a type of horse peculiarly fitted for both through the efforts of Prof. Carlyle, with help from the Federal Department of Agriculture. The nucleus of this new breed is on the agricultural college farm, but the ranchmen of Colorado are aiding in th , work of implanting on the State's ast horse-raising area these large, beauful, and enduring drivers, for which here is an ever-growing demand, both in domestic and foreign markets, notwithstanding the popularity of the automobile.

The governments of the world now Tonsider expenditures for building up the science and the practice of agriculture and the work of creating better types of plants and animals as necesary as expenditures for an army and navy. By both selective and creative breeding, in part under public patronage, increases will continue to be made in the value of ur plant and animal productions equal to our military, naval, and educational expenditures. And without increasing our cultural acreage, there will be plenty of food for as many millions as we are likely to have - all through this new science of breeding.

\section{TYPEWRITER OPERATING WITHODT} NOIBE.

(Concluded from page 4.1.)

surface, flat-faced type are used instead of the ordinary concave type. This overcomes a difficulty common to machines using a rubber roll for the platen in which the diameter of the printing surface varies with the number of copies made, resulting in blurred impressions when the curvature differs materially from that of the type.

In order to produce a noiseless typewriter, it is necessary not merely to keep the key and typebar movement quiet, but to make the escapement, shift, and back spacer movements silent, is well. This result has been accomplished by the use of ratchet pawls and dogs fitted with cam surfaces so that there is no clicking noise whatever. The escapement mechanism is very ingenious. The pinion at the upper end of the escapewheel shaft engages the carriage rack and must be capable of movement to allow for adjusting the carriage toward and from the printing position, as explained above. The escapement pawl, however, is mounted in the flxed part of the machine. In order to allow for such relative movement the shaft is mounted on a globular ball-bearing; that is, the cones of the bearing are spherical, so that there will be no binding, whether the upper part of the shaft is moved forward or to the rear and out of the forma vertical position. The silent cam faced escapement pawl is clearly shown in one of the detail views. Everything has been done to hush the slightest click. Even tuc bell that gives warning when the end of a line has nearly been reached makes a very faint "ting"; but this sound is amply loud, considering the silence of the rest of the machine. Copying OId MSS.-To make old writings plainly legible for copying, dissolve 150 parts of oxalate of ammonia, of potassium, or of sodium, 0.8 part of ferrocyanide of potassium, 0.06 part of vanadate of ammonia in 1,000 parts of water,

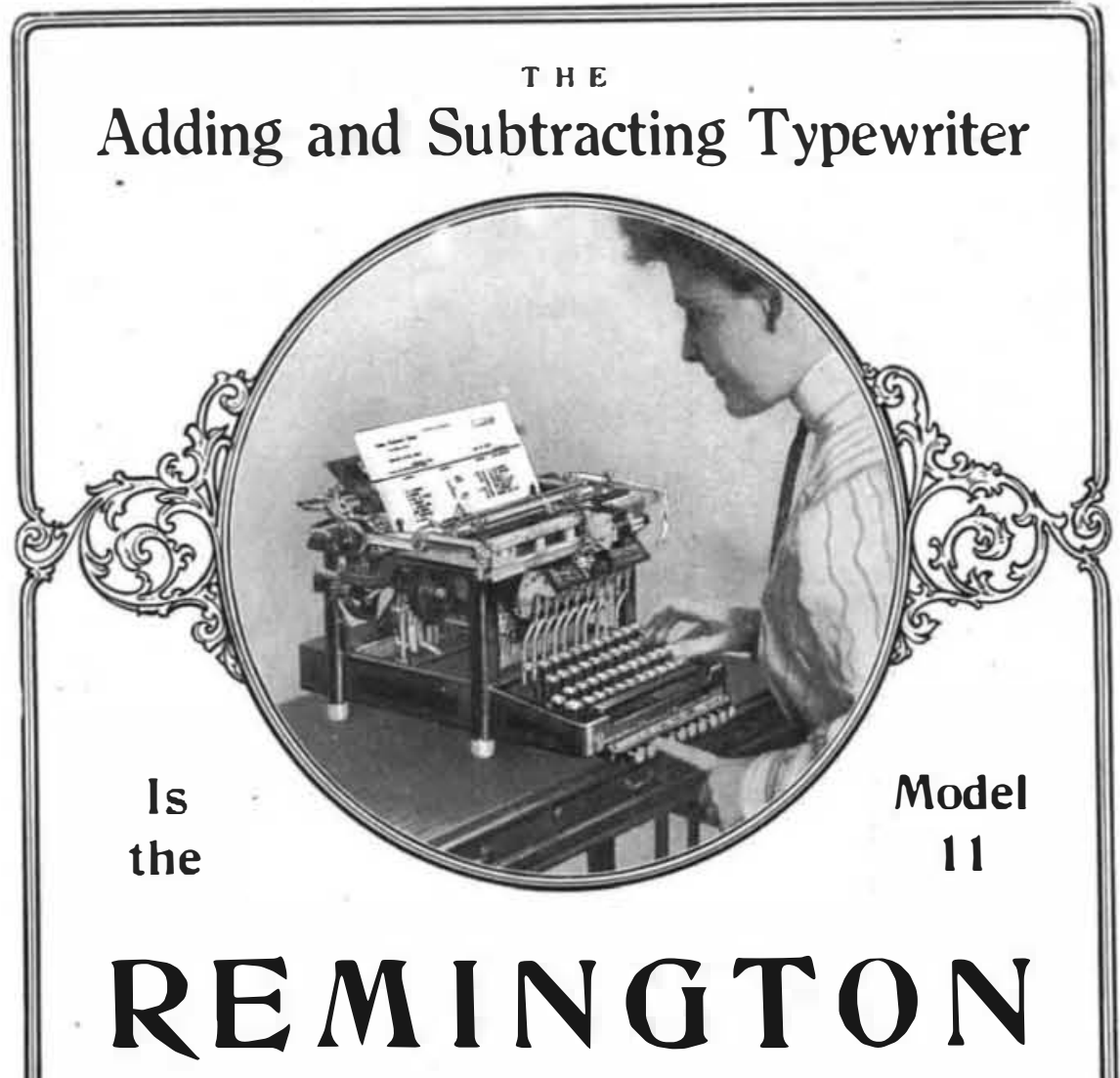

With Wahl Adding and Subtracting Attachment

This is the complete accounting machine - the machine which writes, tabulates, bills, adds, subtracts and auditsthe machine which represents the present acme of clerical labor saving. Catalogue sent on request.

Remington Typewriter Company (Incorporated)

325-327 Broadway, New Vork, or Any City on Earth

\section{American Homes and Gardens}

CONTENTS FOR DECEMBER, 1910

Among the Foothills of the Canadian Rockies . . Frontispiece The Country Seat of Howard Henry, Esq., at Camp Hill, Pa. By Francis Durando Nichols 455

The Art of Ornamental Orange Peeling

By Harold J. Shepstone 461 Decorations and Fumishings for the Home-X. Treatment of

Fireplaces and Mantels, . . By Alice M. Kellogg 463 Old South Salem . By Theodore Langdon Van Norden 466 Artistic Wax Work . . . . . . By Monica Bastin 470 A Group of Modern Houses Costing from \$1,800 Upwards

Handicraftsman-Leather Craftwork, By Catberine A. Jensen 474 Crafts that Children Can Do . By Mabel Tuke Priestman 475 Cstrich Farming as an Industry . . . By Newton Forest 478 T.he Small Country House-A Dutch Colonial House Costing \$2,150 Complete . . . By Paul Thurston 480 A Craftsman's House Costing $\$ 2,400$ Complete . . . . 481 A House of Modern Design Costing \$3,200 Complete . . 482

A House and a Garage . . . . By Robert Prescott 484

Garden Notes . By Charles Downing Lay 485

American Homes and Gardens' Garden Competition--First Garden Prize won by Dr. Shiro Miyaki, St. Louis, Mo. 486

Second Prizé won by James M. Hull, Esq., Hamilton, Ontario, Can.

Third Garden Prize won by M. F. Ault, Indianapolis, Ind. 491 The Editor's Note Book Correspondence American Homes and Gardens for January
Index for 1910

PUBLISHED MONTHLY BY MUNN \& CO., INC. 361 BROADWAY

NEW YORK CITY 